\title{
Artificial irradiation for lettuce plant raising - technical and economic aspects*
}

\section{A. J. de Visser ${ }^{1}$ and J. van de Vooren ${ }^{2}$}

1 Agricultural Economics Research Institute, the Hague, the Netherlands

${ }^{2}$ Glasshouse Crops Research and Experiment Station, Naaldwijk, the Netherlands

\section{Summary}

The effect of irradiation during plant raising of lettuce on the ultimate yield turned out to be determined by plant weight. Starting from this, economic calculations were carried out for two examples. Under the assumed circumstances irradiation seemed no payable proposition.

\section{Introduction}

At the end of the 1960's there was a great deal of interest in the irradiation of lettuce seedlings which was stimulated in particular by English research work (e.g. Canhem, 1971; Rothwell, 1973).

From 1970 until 1973, irradiation of lettuce plants was investigated at the experimental station 'Noord-Limburg' at Venlo in order to establish the effects of lighting on the growth of lettuce during plant raising and after planting out under Dutch conditions (Janssen, 1972a, b, 1973). The data used in this publication were obtained during this research. The original data were published in the internal experimental reports of the experimental station 'Noord-Limburg'. The cultural and technical aspects will be dealt with in the first part of this publication and the economic aspects in the second part.

\section{Technical aspects}

During November and December 1972, lettuce was sown in $4 \times 4 \times 4 \mathrm{~cm}$ soil blocks at three day intervals. The seedlings were grown under natural light or under natural light supplemented with $200 \mathrm{~W} / \mathrm{m}^{2}$ for $16 \mathrm{~h}$ per day. Lamp type TL 33 was used as the light source. A night temperature of $7{ }^{\circ} \mathrm{C}$ and day temperatures of $12,15,18$ and $21{ }^{\circ} \mathrm{C}$ plus a $3{ }^{\circ} \mathrm{C}$ light-dependent increase were maintained. All the seedlings were planted out under identical conditions on 17 January 1973. Samples of the plants were weighed on this date. The weight of the heads was again recorded at harvest on 13 and 22 March. The rapid development of the plants * Publikatie van het Proefstation voor de Groenten- en Fruitteelt onder Glas te Naaldwijk No 206. 


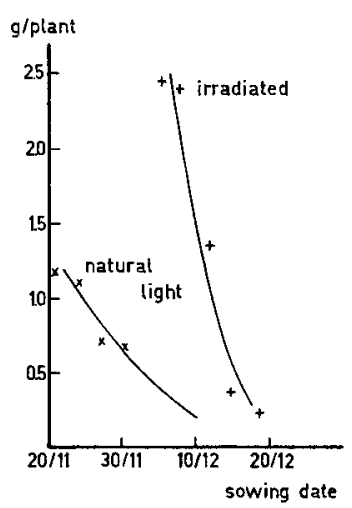

Fig. 1. The effect of the sowing date $(20$ November -20 December 1972) on the weight of lettuce plants in $g$ per plant on 17 January 1973. + denotes irradiated plants and $\times$ plants grown with natural light only. Night temperature $7{ }^{\circ} \mathrm{C}$, day temperatures $21-24{ }^{\circ} \mathrm{C}$.

which were given supplementary light, compared with the untreated plants, was remarkable (see Fig. 1).

Lettuce sown on 28 November (unlit) and on 13 December (lit) reached an average weight of $0.8 \mathrm{~g}$ per plant on 17 January. According to crop physiologists, the lit plants had sturdier and broader leaves than the unlit. With supplementary irradiation, good marketable lettuce plants weighing about $1.3 \mathrm{~g}$ each could be obtained on 17 January from an 11 December sowing, whilst on this date unlit plants from a 28 November sowing weighed only $0.7 \mathrm{~g}$ each.

Fig. 2 shows the effect of plant weight on the yields obtained on 13 and 22 March. During the harvest of 22 March the lit and unlit plants were recorded separately. Irradiated lettuce plants of the same weight as unlit plants at planting out, yielded slightly heavier heads at harvest. The difference was not statistically significant and amounted to $6 \mathrm{~g}$ per head at most. A comparison of the yields on 13 and $22 \mathrm{March}$

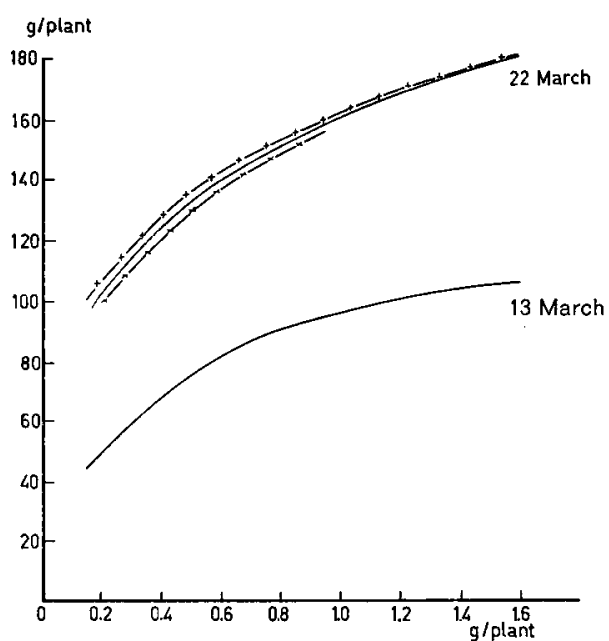

Fig. 2. The effect of plant weight in $g$ per plant at the time of planting out (17 January 1973) on the yield in $\mathrm{g}$ per head of lettuce on two harvesting dates, 13 and 22 March 1973. The crop harvested on 22 March was divided into the plants raised with irradiation $(-+-)$ and those raised with natural light only $(-\times-)$. Night temperature $7{ }^{\circ} \mathrm{C}$. The day temperature treatments, $12-21^{\circ} \mathrm{C}$, were recorded together, 


\section{ARTIFICIAL IRRADIATION FOR LETTUCE PLANT RAISING}

shows that the weight of a lettuce plant is increased by 60 to $70 \mathrm{~g}$ in 9 days, a weight increase of $7 \mathrm{~g}$ in less than one day! There was no significant difference at harvest in the plants raised at different temperatures, but which were of the same weight at the time of planting out. It may be concluded from these data that the pre-planting history of lettuce plants has little or no effect on the ultimate harvest as far as irradiation is concerned, provided the plants are of equal weight at the time of planting out.

\section{Economic aspects}

The calculations have been based on a number of assumptions. The daily cost of the glasshouses has been fixed at $f$ (Dutch guilders) 50 per $1000 \mathrm{~m}^{2}$ which is the equivalent of the net income a grower could expect from a winter crop.

The gas price is $f 80$ per $1000 \mathrm{~m}^{3}$ and the gas consumption has been calculated according to the method worked out by Kostelijk et al. (1966). A transmission figure of 9 for the cropping house and a figure of 10.8 for the propagation house is used. One $\mathrm{m}^{3}$ natural gas produces $7500 \mathrm{kcal}$ at an efficiency of $80 \%$. The periods of plant raising and cropping may be found in the first part of this paper. Of the total glasshouse area $5 \%$ has been allocated to plant raising, assuming that 4-cm soil blocks are used. Per $1000 \mathrm{~m}^{2} 21000$ plants are propagated and 20000 are planted out. Two examples are examined in closer detail.

\subsection{Cost comparison of lit and unlit plants of the same weight}

The difference of the costs of propagating space and energy between a lit and an unlit plant of the same weight $(0.8 \mathrm{~g})$ on 17 January is examined. The lit plant was sown on 13 December, the unlit on 28 November. For irradiation to be viable proposition the plant raising costs with irradiation should be the same - or less - as the plant raising costs without irradiation.

Costs: Irradiation $(13 / 12-17 / 1)+$ propagating space $(13 / 12-17 / 1)+$ energy for propagating space $(13 / 12-17 / 1)$

$<$ propagating space $(28 / 11-17 / 1)+$ energy for propagating space $(28 / 11$ $17 / 1)$

Costs of irradiation $<5 \%$ cropping space $(28 / 11-13 / 12)+5 \%$ energy $(28 / 11$ $-13 / 12)$

$<0.75$ days cropping space $+250 \mathrm{~m}^{3}$ gas

$<f 37.50+f 20$.

This means that a maximum of $f 57.50$ for 20000 plants or $f 0.0029$ per plant is available for irradiation. The electricity consumption for irradiating the plants, based on 600 plants per $\mathrm{m}^{2}$ propagating space and $200 \mathrm{~W}$ per $\mathrm{m}^{2}$ for 16 hours a day, works out at $(21000 / 600) \times 16 \times 0.2=112 \mathrm{kWh}$ per day.

The consumption over 35 days is $3920 \mathrm{kWh}$. At a kWh cost of $f 0.06$ the cost of electricity works out at $f 235.20$ for 20000 plants or $f 0.0118$ per plant. The calculation shows that only $25 \%$ of the cost of electricity is covered. 


\subsection{Cost comparison of plantable lit and unlit plants}

The difference in the costs of propagating space and energy between a lit and unlit plant of plantable size is examined. The irradiated plant weights $1.3 \mathrm{~g}$ on 17 January and was sown on 11 December. The unlit plant weights $0.7 \mathrm{~g}$ on the same date and was sown on 28 November (Fig. 1). The unlit plant requires an extension of the growing period by three days to produce the same weight at harvest as the irradiated plant (Fig. 2). For irradiation to be a payable proposition, the costs of plant raising with supplementary lighting must be lower or the same as the costs of plant raising without supplementary light plus the costs of the extended cropping period.

Costs. Irradiation $(11 / 12-17 / 1)+$ propagating space $(11 / 12-17 / 1)+$ energy for propagating space $(11 / 12-17 / 1)+$ cropping space $(17 / 1-23 / 3)+$ energy for cropping space $(17 / 1-23 / 3)<$ Propagating space $(29 / 11-17 / 1)+$ energy for propagating space $(29 / 11-17 / 1)+$ cropping space $(17 / 1-26 / 3)+$ energy for cropping space $(17 / 1-26 / 3)$.

Costs of irradiation $<5 \%$ cropping space $(29 / 11-11 / 12)+5 \%$ energy $(29 / 11-11 / 12)+$ cropping space $(23 / 3-26 / 3)+$ energy $(23 / 3-26 / 3)$

$<0.6$ days cropping space +3 days cropping space $+220 \mathrm{~m}^{3}$ gas $+750 \mathrm{~m}^{3}$ gas $<f 180+f 78$.

At most a sum of $f 258$ per 20000 plants or $f 0.0127$ per plant is therefore available for irradiation. Electricity consumption for 37 days irradiation is $37 \times 112=$ $4144 \mathrm{kWh}$ (see Section 3.1). At a $\mathrm{kWh}$ price of $f 0.06$ the electricity costs for 20000 plants are $f 248.64$ or $f 0.0124$ per plant. The costs of electricity are therefore just covered.

\section{Conclusions and discussion}

The first part of this publication (see Section $\mathrm{X}$ ) shows that the effect of irradiation on the ultimate yield could be ascribed to a small and insignificant extent only to causes other than plant weight. This is why it was assumed in the economic calculations that plant weight is the only determining factor for the ultimate yield. Janssen (1972b) assessed the total cost of irradiation at $f 0.026$ per plant, of which about $30 \%$ is the cost of electricity. According to these calculations, the acceptable costs or irradiation amount to $10 \%$ of the total irradiation costs if the cropping period remains the same (see Section 3.1) and to $50 \%$ if the cropping period is shortened by irradiation treatment (see Section 3.2). It should be noted that these calculations are valid only for our basic factors such as the time of year and the assumed economic data. It might well be that irradiation is a paying proposition under different circumstances.

\section{Acknowledgment}

The authors are very much indebted to G. A. J. Janssen of the experimental station 'Noord-Limburg' for making available the original results of the lettuce irradiation experiments 1972/1973. 


\section{ARTIFICIAL IRRADIATION FOR LETTUCE PLANT RAISING}

\section{References}

Canham, A. E. (Ed.), 1971. Symposium on electricity and artificial light in horticulture, 1969. Tech. Commun. int. Soc. hort. Sci. 22; 234 pp.

Janssen, G. A. J., 1972a. [Lettuce experiments 1971-1972.] Experimental Station 'Noord-Limburg', Venlo, 16 pp. (in Dutch).

Janssen, G. A. J., 1972b. [Irradation of plants.] Groenten en Fruit 28: 351-355 (in Dutch).

Janssen, G. A. J., 1973. [Report of glasshouse vegetable experiments, 1973.] Experimental Station 'Noord-Limburg', Venlo, p. 20-24 (in Dutch).

Kostelijk, S. \& C. P. Withagen, 1966. [Cost comparisons of heating with 3.500 sec. Redwood I oil and natural gas.] Inst. TuinbTech., Wageningen 5; 12 pp. (in Dutch).

Rothwell, J. B., 1973. Raising lettuce seedlings under fluorescent lighting. Exp. Hort. 25: 119-126. 